\title{
54. LIQUID LINES OF DESCENT OF BASALTS DRILLED AT SITES 794 AND 797 IN THE YAMATO BASIN OF THE JAPAN SEA ${ }^{1}$
}

\author{
P. Thy ${ }^{2}$
}

\begin{abstract}
The flows and sills drilled at Sites 794 and 797 in the Yamato Basin of the Japan Sea are subalkalic, olivine, and/or plagioclase phyric basalts. Compositionally, the rocks can be divided into a depleted, low-K type and an enriched, relatively high- $\mathrm{K}$ type. In addition, two contrasting evolution trends are reflected in the rock compositions, which allow four different magmatic suites to be identified. It is suggested that the depleted or enriched nature of these suites represent primary characteristics, while the different evolution trends are related to fractionation processes in crustal magma chambers. A tholeiitic evolution trend, with increasing $\mathrm{FeO}$ and $\mathrm{TiO}_{2}$ and decreasing $\mathrm{Al}_{2} \mathrm{O}_{3}$, can be modelled by fractional crystallization of $40 \%-50 \%$ plagioclase, olivine, and augite. A mildly calc-alkalic evolution trend, with decreasing $\mathrm{FeO}$, increasing $\mathrm{Al}_{2} \mathrm{O}_{3}$, and nearly constant $\mathrm{TiO}_{2}$, can be modelled by $8 \%-12 \%$ olivine fractionation. Mineralogical evidence suggests that these differences may be related to the effect of small amounts of water during crystallization of the calc-alkalic suites. The tholeitic suites occur in the lower parts of the drill cores, while the calc-alkalic suites occur in the upper parts. This suggests a complex tectonic and magmatic evolution, perhaps reflecting a transition between calc-alkalic magmatism related to subduction zone activity and tholeitic magmatism related to back-arc spreading. Furthermore, any magmatic model must be able to account for the range in parental magmas from depleted to enriched throughout the tectonic history of the Yamato Basin.
\end{abstract}

\section{INTRODUCTION}

Drilling during Legs 127 and 128 in the Japan Sea recovered for the first time extensive sections of basaltic basement. Besides a few lava flows, this basement is composed of mainly thick sill complexes, intruded into soft, water-rich sediments (Ingle, Suyehiro, von Breymann, et al., 1990; Tamaki, Pisciotto, Allan, et al., 1990). The recovered rocks are compositionally subalkalic (Fig. 1). A detailed petrographic investigation (Thy, this volume, a) suggested the presence of three distinct types of basalts, which could be identified by their mineral assemblages and chemistry of phenocrysts and groundmass phases. The first type is augite phyric, arc tholeiitic basalt and andesite flows found at Site 795 in the Japan Basin. The second type, which was recovered at Sites 794 and 797 in the Yamato Basin, is relatively $\mathrm{K}$-depleted, olivine phyric, basaltic sills. The third type, recovered at both Sites 794 and 797 , is dominantly composed of $\mathrm{K}$-enriched, olivine-free, basaltic sills; however, some olivine phyric, basaltic sills from Site 794 also belong to this suite. As used in this chapter, enriched and depleted refer to the relative K-depleted or $\mathrm{K}$-enriched nature of the rocks and constituent minerals; this division is substantiated by trace element studies (Cousens and Allan, this volume).

This chapter attempts to reconcile the observed compositional variation of the basalts of Sites 794 and 797 with the experimental phase equilibria obtained during a low-pressure, experimental investigation of an olivine basalt from Site 797 (Thy, this volume, b). In addition, the relationship of the Japan Sea rocks to the middle Miocene, back-arc volcanic sequences of northeastern Japan is discussed briefly.

\footnotetext{
' Tamaki, K., Suyehiro, K., Allan, J., McWilliams, M., et al., 1992. Proc. ODP, Sci. Results, 127/128, Pt. 2: College Station, TX (Ocean Drilling Program).

2 Department of Geology, University of Botswana, Private Bag 0022, Gaborone, Botswana.
}

\section{DISCUSSION}

\section{Magma Suites}

Simplified stratigraphic columns for Sites 794 and 797 are shown in Figure 2; detailed petrographic descriptions can be found in Thy (this volume, a). An upper suite at Site 794 is composed of plagioclase and sometime olivine phyric, doleritic sills with $\mathrm{Mg} /\left(\mathrm{Mg}+\mathrm{Fe}^{2+}\right)$ ratios between 0.58 and 0.72 . The uppermost, evolved sills contain occasionally phenocrysts of calcic plagioclase $\left(\mathrm{An}_{85-91}\right)$. Alower suite at Site 794 is composed of plagioclase and olivine phyric, basaltic sills with $\mathrm{Mg} /\left(\mathrm{Mg}+\mathrm{Fe}^{2+}\right)$ ratios mostly between 0.60 and 0.67 . An upper suite of sills at Site 797 is composed of sparsely plagioclase and olivine phyric to aphyric, basaltic sills with $\mathrm{Mg} /\left(\mathrm{Mg}+\mathrm{Fe}^{2+}\right)$ ratios between 0.64 and 0.72 . A lower suite at Site 797 is composed of aphyric to plagioclase phyric, basaltic sills with $\mathrm{Mg} /\left(\mathrm{Mg}+\mathrm{Fe}^{2+}\right)$ ratios between 0.56 and 0.60 .

An argument against cogenetic suites is provided by the distinct differences in the $\mathrm{K}$ content of groundmass plagioclase, compared to similar An content, which clearly separates a high-K magma type, represented by the upper suite at Site 794 and the lower suite at Site 797 , and a low-K type, represented by the lower suite at Site 794 and the upper suite at Site 797 (Fig. 2). Therefore, it is suggested (Thy, this volume, a) that the observed suites of rocks represent two distinct and unrelated magma types that in terms of $\mathrm{K}$ contents were either depleted or enriched.

The lavas collected from Site 795 are not discussed in details because of extensive secondary modifications. However, the available analyses (Tamaki, Pisciotto, Allan, et al., 1990) suggest an upper, andesitic suite and a lower, basaltic suite. This is substantiated by the mineral chemistry (Thy, this volume, a).

\section{Oxide Variation Diagrams}

Despite an extensive hydration and alteration of the sills, from intrusion into water-rich sediments, their original compositions can be inferred for most of the drilled sites. The relatively unaltered samples analyzed by shipboard X-ray fluorescence (Ingle, Suyehiro, 


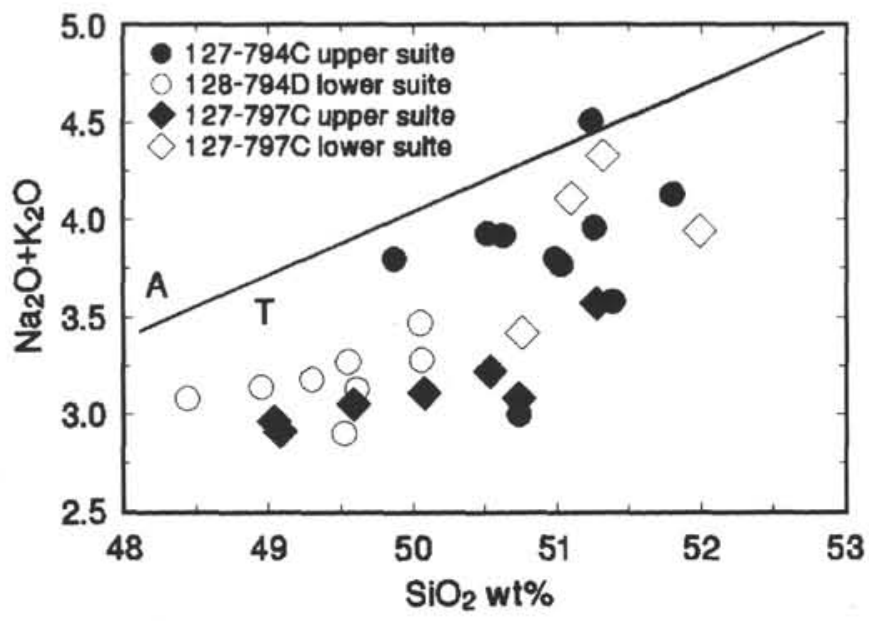

Figure 1. Alkali $\left(\mathrm{Na}_{2} \mathrm{O}+\mathrm{K}_{2} \mathrm{O}\right)$ vs. silica $\left(\mathrm{SiO}_{2}\right)$ diagram for the Yamato Basin rock. Data and calculation are as for Figure 3. The division between alkalic (A) and tholeiitic (T) rocks is from MacDonald and Katsura (1964).

von Breymann, et al., 1990; Tamaki, Pisciotto, Allan, et al., 1990) are given in Table 1. In addition to the shipboard analyses, data obtained by S. Yamashita and A. Pouclet (pers. comm., 1990) were available and are shown in subsequent figures. The selected analyses show relatively well-constrained groupings for elements and ratios susceptible to secondary alteration; this suggests that despite extensive alteration for many samples, the general compositional characteristics of the rock suites can be identified.

Several features become apparent from inspection of Figure 3. The enriched sills of Site 794 show a marked departure from the experimental, one-atmosphere liquid line of descent, reaching for low-MgO, relatively high- $\mathrm{Al}_{2} \mathrm{O}_{3}$, low-FeO, and nearly constant $\mathrm{TiO}_{2}$ contents. This contrasts with the enriched basalts of Site 797 that reach low- $\mathrm{Al}_{2} \mathrm{O}_{3}$ and high-FeO contents and conform with the experimental results. Increasing $\mathrm{TiO}_{2}$ and $\mathrm{FeO}$ and decreasing $\mathrm{Al}_{2} \mathrm{O}_{3}$ are typical features of low-pressure, liquid lines of descent. The absence of these features for the evolved basalts of Site 794 requires different petrogenetic processes. In the $\mathrm{K}_{2} \mathrm{O}+\mathrm{Na}_{2} \mathrm{O}-\mathrm{FeO}$ $\mathrm{MgO}$ diagram of Figure 4, the two trends reflect their different $\mathrm{Fe}$-enrichments; the Fe-enrichment trend plots above the tholeiitic/calc-alkalic dividing line of Irvine and Baragar (1971), while the Fe-depletion trend plots below this line. Therefore, the Fe-enrichment trend is tholeiitic, and the Fe-depletion trend is mildly calc-alkalic.

Only a few, relatively fresh samples of the high-Mg basalts (MgO $\sim 9-10 \mathrm{wt} \%$ ) of the upper, enriched suite at Site 794 were analyzed (Table 1). Judging from the variation diagrams (Fig. 3), as well as the detailed mineral chemistry (Thy, this volume, a), these can be related to the evolved basalts of the same suite. The variation diagrams for $\mathrm{CaO}$ and $\mathrm{SiO}_{2}$, however, reveal that the analyzed rocks have been altered by hydrothermal processes. The depleted suites at Sites 794 and 797 vary widely in their $\mathrm{MgO}$ contents; but the basalts from Site 794 have significantly higher $\mathrm{FeO}$ and $\mathrm{TiO}_{2}$ contents that may suggest petrogenetic similarities between these and the enriched suite of Site 797.

In summary, there are four distinct magma suites represented among the rocks drilled at Sites 794 and 797 (Fig. 3). These can be identified by their depleted or enriched nature, besides whether they follow calc-alkalic or tholeiitic evolution trends (Fig. 2). The upper suite at Site 794 is of the enriched magma type and follows a calc-alkalic evolution trend, while the lower suite is depleted and follows a tholeiitic evolution trend. The upper suite at Site 797 is depleted and calc-alkalic, in contrast to the lower suite at the same site, which belongs to the enriched magma type and is tholeiitic.

\section{Phase Equilibria}

Together with experimentally determined liquid lines of descent, the relatively fresh basalts have been projected into the normative basalt tetrahedron (Fig. 5), using a CIPW molecular norm and following the procedure outlined by Presnall et al. (1979). Iron has been distributed between $\mathrm{Fe}^{2+}$ and $\mathrm{Fe}^{3+}$ according to Kilinc et al. (1983), and assumes the fayalite-magnetite-quartz (FMQ) oxygen buffer and temperatures based on the experimental results of Thy (this volume, b). It is apparent from Figure 5 that all the analyzed rocks are olivineand hypersthene-normative, which is consistent with their subalkalic nature in the alkali-SiO ${ }_{2}$ diagram (Fig. 1). An additional observation is that the enriched suites contain higher normative hypersthene compared to the depleted suites (Fig. 5). The large scatter in normative diopside is probably related to variable amounts of alteration.

For comparison, the experimental, one-atmosphere, plagioclase, olivine, and augite saturated cotectic for mid-ocean ridge basalts (marked "MORB") using experimental data of Walker et al. (1979), Grove and Bryan (1983), and Tormey et al. (1987) is shown in Figure 5. There is a good correspondence between the liquid line of descent for mid-ocean ridge basalts and those for the Site 797 sills (marked "JS"). However, it is clear, as already known from the petrographic examination, that the Japan Sea rocks are saturated in plagioclase and olivine or plagioclase only and plot away from the pseudo-univariant saturated cotectic; augite appears during groundmass crystallization. Exceptions are the basalts and andesites from Site 795, which are saturated in plagioclase and augite, but are not shown in Figure 5. Because plagioclase and olivine fractionation for Sites 794 and 797 magmas will result in increasing normative diopside (Fig. 5), the difference between the depleted and the enriched suites is a primary feature.

\section{Augite-Liquid Relations}

Except for Site 795, all analyzed natural augites are groundmass phases. The relatively late appearance of augite in the melting experiments, therefore, justifies a comparison between the experimental and the natural augites. These, together with the experimental coexisting augites and liquids, are plotted in Figure 6 . The bulk of the natural augites are dominantly nepheline-normative, or are shifted away from normative quartz, compared to the experimental augites (Fig. 6). Only the augites from the arc tholeiitic suite at Site 795 and from the depleted, tholeiitic suite at Site 797 trend toward hypersthene-normative compositions, similar to those of the experiments. The experimental augites of the Japan Sea rock are typical for one-atmosphere, anhydrous experiments on enriched to depleted tholeiitic and calc-alkalic rocks (Fig. 7A). Despite this, the natural augites of the calc-alkalic suites are best compared to experimental augites of mildly alkalic basalts (i.e., nepheline-normative). There are indications that some of the depleted rocks from Sites 794 and 797 are slightly more olivine-normative than the experimental liquids (Fig. 5). Therefore, transitional types of augites, between mildly alkalic and tholeiitic types (Fig. 7A), could be expected. Nevertheless, this will not explain the observations, as the calc-alkalic suites, which contain nephelinenormative augites, include enriched magma types. Furthermore, the andesitic augites of Site 795, which presumably crystallized from quartz-normative melts, are nepheline-normative. An additional observation is that the andesitic and tholeiitic suites contain augites with slightly lower normative diopside compared to the calc-alkalic suites.

An explanation for the discrepancies between the experimental and the observed natural augites is not evident. The effects of cooling rate and metastable crystallization of augite may be evaluated from the experimental work of Baker and Grove (1985), among many others. The effect of slow cooling rates on augite composition is a decrease in the wollastonite component and an increase in the enstatite-ferrosilite and nonquadrilateral components. When plotted on the 
794B-C 794D

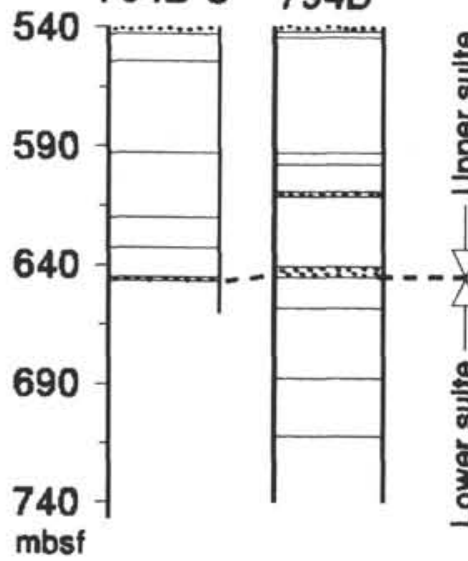

$\mathrm{K}(\mathrm{O}=8) \quad \mathrm{Mg} /\left(\mathrm{Mg}+\mathrm{Fe}^{2+}\right)$

An70 Rock

Enriched $\sim 0.008 \quad 0.58-0.72$

Calc-

alkalic

Depleted $\sim 0.003 \quad 0.60-0.67$

mbsf

$\square$ Dike/flow
Sediment

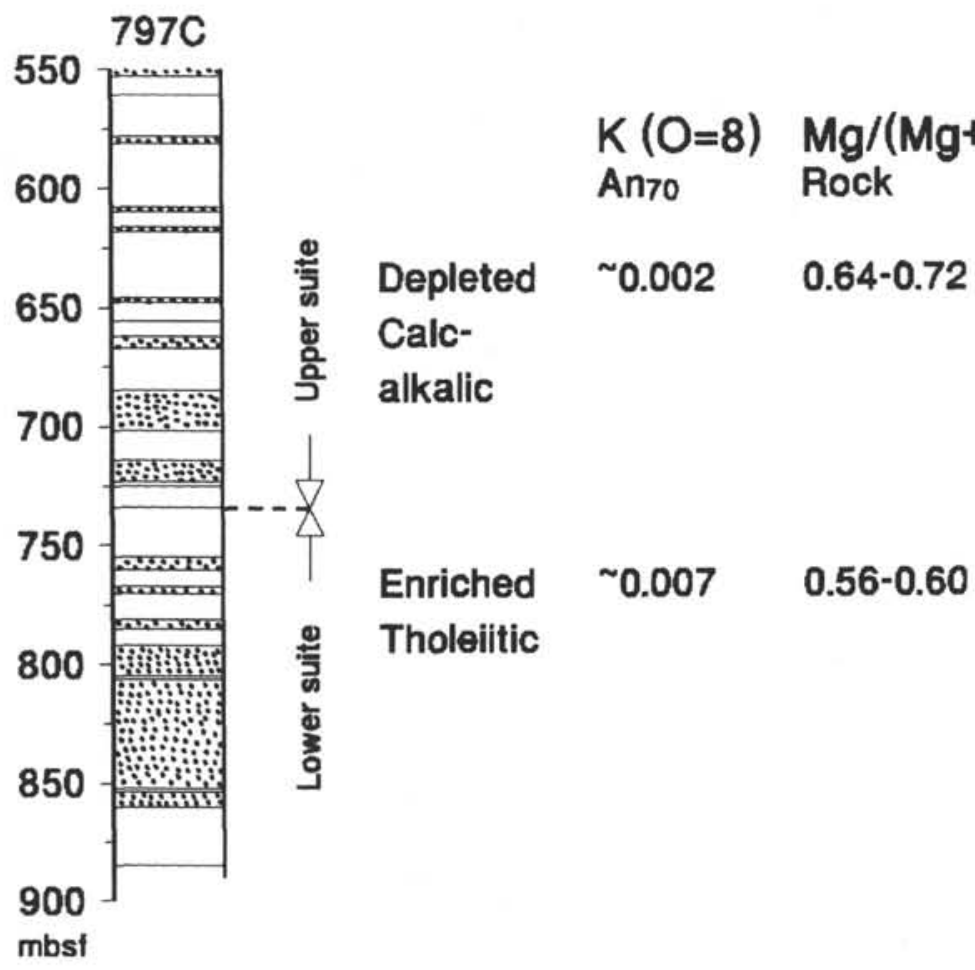

Figure 2. Simplified stratigraphic columns for Sites 794 and 797 indicating the rock suites and their compositional characteristics. The potassium content of plagioclase (cations based on 8 oxygens) is given relatively to $A n_{70}$. The $\mathrm{Mg} /\left(\mathrm{Mg}+\mathrm{Fe}^{2+}\right)$ is the whole rock composition and is calculated as for Figure 3. For stratigraphic details, see Ingle, Suyehiro, von Breymann, et al. (1990) and Tamaki, Pisciotto, Allan, et al. (1990). Further petrographic details and discussions of the division into magmatic suites can be found in Thy (this volume, a).

normative diagram of Figure 7B, clearly metastable crystallization of augite cannot explain the nepheline-normative augites. This is also evident if it is considered that many augites in the calc-alkalic suite at Site 797 texturally are skeletal and still straddle the normative divide (Fig. 6).

The effect of anhydrous pressure on augite compositions is basically similar to that observed for metastable growth. This can be illustrated by the work of Baker and Eggler (1987) in Figure 7C, which shows a marked decrease in the wollastonite component, together with an increase in particular the Ca-tschermakite component for $8 \mathrm{kbar}$ anhydrous conditions relative to one-atmosphere (see also Biggar, 1984; Thy, 1991). Water-saturated crystallization may widen the immiscibility gap between the two pyroxenes and increase the wollastonite component (Helz, 1973; Biggar, 1984), although the actual $\mathrm{P}_{\mathrm{H}, \mathrm{O}}$ appears to have less effect (Lindsley, 1983). Water-undersaturated crystallization also may increase the wollastonite component, but has little effect on the Ca-tschermakite component, compared to anhydrous conditions (e.g., Green and Ringwood, 1968). 
Table 1. Selected shipboard X-ray fluorescence analyses of relatively fresh rocks, Sites 794 and 797.

\begin{tabular}{|c|c|c|c|c|c|c|c|c|c|c|c|c|c|c|}
\hline Sample & $\mathrm{SiO}_{2}$ & $\mathrm{TiO}_{2}$ & $\mathrm{Al}_{2} \mathrm{O}_{3}$ & $\mathrm{Fe}_{2} \mathrm{O}_{3}$ & $\mathrm{FeO}$ & $\mathrm{MnO}$ & $\mathrm{MgO}$ & $\mathrm{CaO}$ & $\mathrm{Na}_{2} \mathrm{O}$ & $\mathrm{K}_{2} \mathrm{O}$ & $\mathrm{P}_{2} \mathrm{O}_{5}$ & Mg\# & $\mathrm{Zr}$ & $\mathrm{Ni}$ \\
\hline \multicolumn{15}{|l|}{ Site 794 upper suite } \\
\hline 794C-2R-1, 34-36 & 51.24 & 1.38 & 18.97 & 1.22 & 7.08 & 0.13 & 5.74 & 9.43 & 3.82 & 0.69 & 0.30 & 0.591 & 103 & 15 \\
\hline $794 \mathrm{C}-3 \mathrm{R}-1,122-124$ & 49.87 & 1.13 & 20.89 & 1.14 & 6.89 & 0.12 & 5.37 & 10.60 & 3.26 & 0.54 & 0.20 & 0.582 & 77 & 16 \\
\hline $794 C-4 \mathrm{R}-1,42-44$ & 50.52 & 1.08 & 19.96 & 1.12 & 6.70 & 0.13 & 5.90 & 10.46 & 3.34 & 0.59 & 0.22 & 0.611 & 88 & 17 \\
\hline 794D-3R-3, 89-94 & 50.63 & 1.29 & 18.32 & 1.33 & 7.91 & 0.12 & 6.65 & 9.61 & 3.29 & 0.63 & 0.21 & 0.600 & 90 & 21 \\
\hline $794 C-12 R-4,85-86$ & 51.39 & 1.33 & 17.11 & 1.03 & 6.49 & 0.16 & 9.50 & 9.17 & 2.86 & 0.72 & 0.23 & 0.723 & 108 & 80 \\
\hline
\end{tabular}

Site 794 lower suite

794D-13R-1, 81-84
794D-14R-1, 81-84
794D-17R-1, 97-100
794D-18R-1, 44-47
794D-19R-1, 11-14
794D-20R-1, 20-23

$\begin{array}{llll}49.61 & 1.54 & 15.34 & 1.5 \\ 50.05 & 1.67 & 15.37 & 1.6 \\ 49.52 & 1.56 & 17.80 & 1.36 \\ 50.06 & 1.69 & 18.05 & 1.1 \\ 48.95 & 1.53 & 17.49 & 1.35 \\ 48.44 & 1.50 & 16.90 & 1.44\end{array}$

$\begin{array}{ll}1.59 & 9.17 \\ 1.65 & 9.19 \\ 1.30 & 7.92 \\ 1.14 & 6.89 \\ 1.39 & 8.33 \\ 1.40 & 8.46\end{array}$

$\begin{array}{lllll}9.17 & 0.18 & 8.43 & 10.84 & 2.8 \\ 9.19 & 0.21 & 7.20 & 11.01 & 3.2 \\ 7.92 & 0.28 & 7.59 & 10.94 & 2.6 \\ 6.89 & 0.27 & 7.49 & 10.91 & 3.0 \\ 8.33 & 0.20 & 8.08 & 10.73 & 2.9 \\ 8.46 & 0.21 & 9.50 & 10.33 & 2.86\end{array}$

2.89
3.23
2.69
3.06
2.94
2.86

$\begin{array}{rrrrr}0.24 & 0.16 & 0.621 & 90 & 129 \\ 0.24 & 0.17 & 0.583 & 95 & 117 \\ 0.21 & 0.18 & 0.631 & 97 & 108 \\ 0.22 & 0.19 & 0.660 & 107 & 124 \\ 0.20 & 0.17 & 0.634 & 92 & 137 \\ 0.22 & 0.17 & 0.667 & 92 & 124\end{array}$

797C-10R-1, 90-92
797C-12R-2, 81-83
797C-12R-4, 35-37
797C-13R-2, 70-72
797C-18R-3, 60-62
797C-19R-2, 42-44
797C-24R-5, 38-40

$\begin{array}{lll}50.83 & 1.13 & 19.34 \\ 48.38 & 0.97 & 18.00 \\ 48.49 & 0.96 & 18.08 \\ 49.58 & 1.00 & 18.60 \\ 49.94 & 0.91 & 18.36 \\ 50.26 & 0.90 & 18.38 \\ 49.15 & 0.94 & 17.82\end{array}$

1.02
1.12
1.09
1.10
1.05
0.97
1.15

5.92
6.62
6.55
6.38
6.09
5.75
6.82

$\begin{array}{rrr}0.42 & 6.29 & 11.00 \\ 0.17 & 9.98 & 11.38 \\ 0.16 & 10.12 & 11.29 \\ 0.32 & 7.62 & 11.92 \\ 0.34 & 8.04 & 11.69 \\ 0.29 & 8.31 & 11.83 \\ 0.18 & 8.96 & 11.87\end{array}$

3.08
3.22
3.09
3.34
3.43
3.16
2.87

$\begin{array}{rrrrr}0.11 & 0.14 & 0.654 & 97 & 150 \\ 0.06 & 0.11 & 0.729 & 77 & 163 \\ 0.05 & 0.12 & 0.734 & 75 & 165 \\ 0.04 & 0.10 & 0.680 & 73 & 145 \\ 0.06 & 0.09 & 0.702 & 54 & 102 \\ 0.07 & 0.08 & 0.720 & 54 & 101 \\ 0.12 & 0.10 & 0.701 & 67 & 94\end{array}$

Site 797 lower suite

797C-31R-2, 36-38

$51.86 \quad 1.70$

15.39

1.52

8.18

0.20

6.33

10.36

3.66

0.54

0.25

0.580

$160 \quad 36$

Note: Relatively unaltered samples, analyzed using shipboard X-ray fluorescence from Ingle, Suyehiro, von Breymann, et al. (1990) and Tamaki, Pisciotto, Allan, et al. (1990). Major and minor elements are in wt\%, while trace elements are in ppm. All analyses are calculated anhydrous, and $\mathrm{Fe}^{2+} / \mathrm{Fe}^{3+}$ normalized as described by Thy (this volume, b). $\mathrm{Mg} \#$ is $\mathrm{Mg} /\left(\mathrm{Mg}+\mathrm{Fe}^{2+}\right)$. Note that samples analyzed or reanalyzed by $\mathrm{S}$. Yamashita and $\mathrm{A}$. Pouclet (pers, comm., 1990) are not included in this table, but may be plotted in the variation diagrams.

Unfortunately, there are little data available on the effect of moderate pressures and low-water activities on augite compositions (cf. Biggar, 1984). A set of data from Baker and Eggler (1987) shows that augites crystallized at $2 \mathrm{kbar}$ with water added are similar to those crystallized anhydrous at $1 \mathrm{~atm}$ (Fig. 7C). Tormey et al. (1987) performed experiments at 1 atm and 2 kbar on a hypersthene-normative basalt and obtained calcic and nepheline-normative augites in their $2 \mathrm{kbar}$ experiments (Fig. 7D). However, the $2 \mathrm{kbar}$ liquids gained significant amounts of Na during the experiments. Tormey et al. (1987) corrected the liquids for this excess $\mathrm{Na}$; but their 2 kbar augites may actually have equilibrated with a highly nepheline-normative liquid and not with a hypersthene-normative, recalculated liquid (Fig. 7D).

Despite the lack of good experimental evidence, it is suggested that relatively nepheline-normative augites found in many Japan Sea basalts may be the result of crystallization at slightly elevated pressures and water activities. If this is correct, the lower, tholeiitic suite at Site 797 and the arc tholeiitic suite at Site 795 record low-pressure and nearly anhydrous conditions. In contrast, the upper, calc-alkalic suites at Sites 794 and 797 and the andesites at Site 795 may record relatively hydrous conditions. However, the tholeiitic suite at Site 794 does not easily conform with this interpretation. Clearly, these possibilities deserve further work.

The calcic plagioclases present in the evolved, calc-alkalic sills of Site 794 might reflect partial crystallization under elevated waterpressures, as suggested by Arculus and Wills (1980) for nodules and inclusions from the Lesser Antilles island arc. S. Yamashita (pers. comm., 1991) suggests a combination of moderate pressures ( 2-3 kbar) and olivine fractionation to account for the evolution of the evolved rocks at Site 794. The effect of anhydrous pressure will be to raise liquidus temperatures and suppress plagioclase crystallization relatively to the mafic phases. A consequence will be an increase in $\mathrm{Na}$ content of the liquid and, therefore, relatively Na-rich plagioclases (Green et al., 1979). The effect of water-undersaturated conditions on plagioclase compositions was investigated by Rutherford and Devine (1988) and Johnson and Rutherford (1989) for dacitic melts. They showed that increasing water activity for constant total pressures should increase the anorthite content of equilibrium plagioclase (coexisting with amphibole). Also, the experimental results of Johnson and Rutherford (1989) showed (1) that the orthoclase component of plagioclase for constant pressure decreases as a function of the mole fraction of $\mathrm{H}_{2} \mathrm{O}$ in the melt and (2) that total pressure for constant water content should have the same general effect. However, for the Japan Sea rocks, high anorthite content of plagioclase phenocrysts is found in rocks which also contains plagioclase with high orthoclase. Furthermore, only the upper suite at Site 794 contains calcic plagioclases and at the same time wollastonite-rich and nepheline-normative augites, above suggested to indicate high water activity. Therefore, the compositions of the Japan Sea plagioclases do not unambiguously support the suggestion that the nepheline-normative nature of the groundmass augites reflect high water activity during solidification.

\section{Calculated Fractionation Models}

Crystallization models that simulate the compositional variation observed in the Japan Sea rocks are illustrated in Figure 8 and tabulated in Table 2 . These models assume perfect crystal fractionation of a depleted olivine basalt from Site 797 (Sample 127-797C$12 \mathrm{R}-2,74-79 \mathrm{~cm}$; Thy, this volume, b) and were performed with a computer code originally developed by Conrad (1987). The calculations were made by incrementally removing crystallizing phases (increments of $2 w t \%$ ), and by assuming perfect Rayleigh fractionation for both major and minor elements (Hanson and Langmuir, 1978; Conrad, 1987). The distribution of $\mathrm{Fe}$ and $\mathrm{Mg}$ between liquid and olivine or augite, and $\mathrm{Na}$ and $\mathrm{Ca}$ between liquid and plagioclase, were based on constant $\mathrm{K}_{\mathrm{D}} \mathrm{s}$ determined by Thy (this volume, b). Using the variable $\mathrm{K}_{\mathrm{D}}$ experimentally determined for plagioclase 

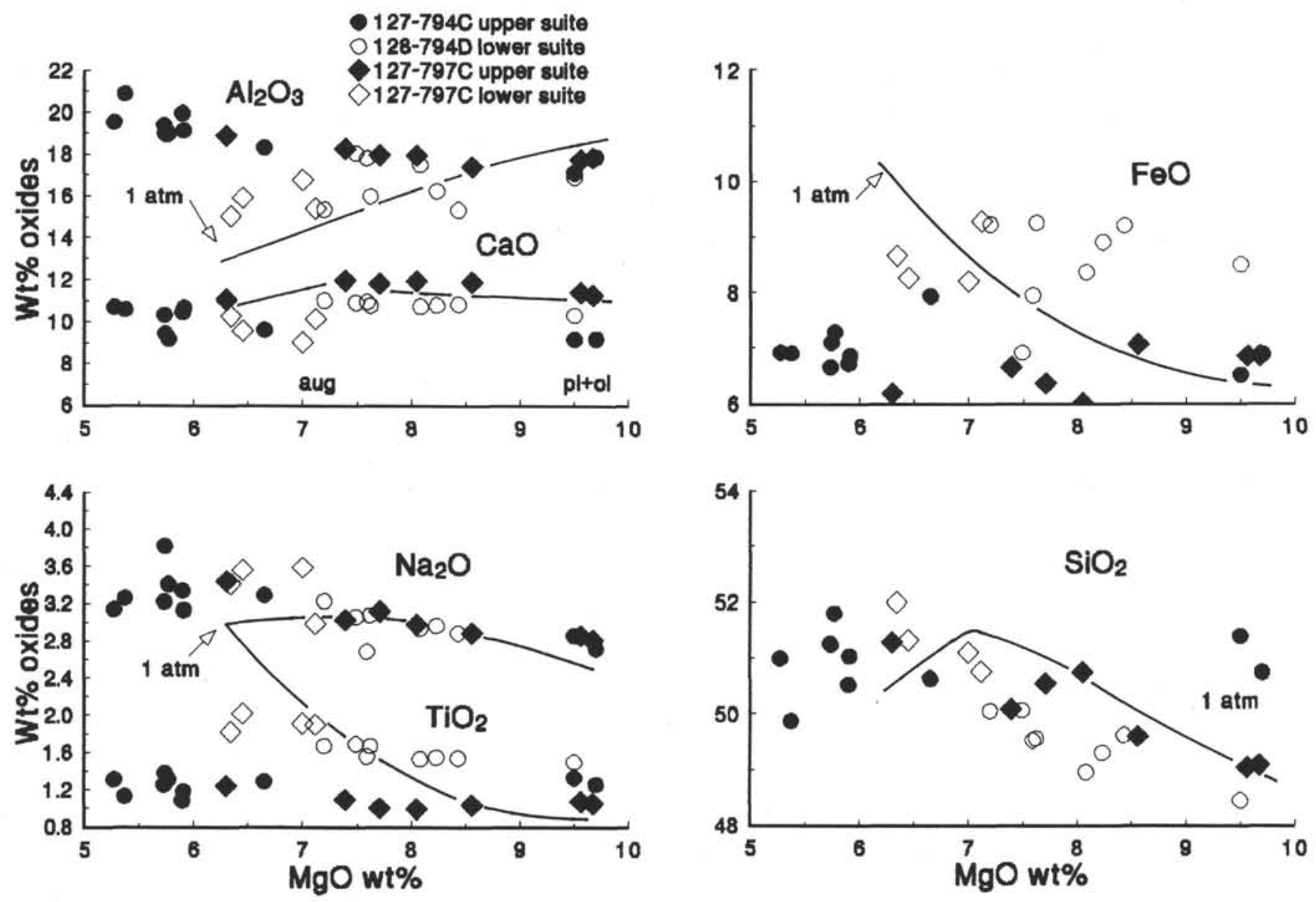

Figure 3. $\mathrm{MgO}$ variation diagrams for $\mathrm{Al}_{2} \mathrm{O}_{3}, \mathrm{CaO}, \mathrm{Na}_{2} \mathrm{O}, \mathrm{TiO}_{2}, \mathrm{FeO}$, and $\mathrm{SiO}_{2}$ (wt\% oxides) of relatively unaltered Yamato Basin, Sites 794 and 797 basalts. All analyses have been calculated anhydrous with $\mathrm{Fe}$ distributed between $\mathrm{FeO}$ and $\mathrm{Fe}_{2} \mathrm{O}_{3}$ after Kilinc et al. (1983), assuming the FMQ oxygen buffer and temperatures based on the experimental results $\left(\mathrm{T}^{\circ} \mathrm{C}=933.8+430.5 \mathrm{MG} ; \mathrm{R}=0.977 ; \mathrm{MG}=\mathrm{Mg}\left(\mathrm{Mg}+\mathrm{Fe}^{\text {total }}\right)\right)$. The lines marked "1 atm" are the experimental liquid line of descent for a sample from Site 797 (Thy, this volume, b). The approximate start of crystallization of augite (aug) and plagioclase and olivine ( $\mathrm{pl}+\mathrm{ol}$ ) are indicated along the $\mathrm{MgO}$-axis of the $\mathrm{Al}_{2} \mathrm{O}_{3}-\mathrm{CaO}$ variation diagram.

will change the actual slopes of the fractionation lines, especially for $\mathrm{Na}$, but will not affect the conclusions significantly; the models shown in Figure 8 and tabulated in Table 2 use an intermediate $\mathrm{K}_{\mathrm{D}} \mathrm{Na} / \mathrm{Ca}$ (pl/liq) value of 0.75 .

Two fractionation paths are shown in Figure 8. The first was obtained by removing the crystallizing phases in the proportions that were experimentally determined $\left(\mathrm{ol}_{29} \mathrm{pl}_{71}\right.$ and $\left.\mathrm{ol}_{22} \mathrm{cpx}_{11} \mathrm{pl}_{67}\right)$. The second assumes fractionation of olivine only $\left(\mathrm{ol}_{100}\right)$, which is equivalent to suppressed plagioclase fractionation. Upon inspection of Figure 8, it can be seen that these two models in general describe the observed differentiation trends. The calc-alkalic, FeO-depletion and $\mathrm{Al}_{2} \mathrm{O}_{3}$-enrichment trends, with nearly constant $\mathrm{TiO}_{2}$, can be explained by $8 \%-12 \%$ fractionation of olivine. The tholeiitic, $\mathrm{FeO}-$ and $\mathrm{TiO}_{2}-$ enrichment trends, in contrast, can be described by $40 \%-50 \%$ fractionation of first plagioclase and olivine, until a $\mathrm{MgO}$ content of 7.2 $w t \%$ is reached and thereafter plagioclase, olivine, and augite. Apparently, augite has little effect on the general fractionation trends; still, the addition of small amounts of augite to the olivine crystallization model may enhance the fit of the calculated curve for low-MgO basalts (Fig. 8).

The suggested suppression of plagioclase crystallization temperature for the calc-alkalic evolution trend is $50^{\circ}-60^{\circ} \mathrm{C}$, relative to anhydrous crystallization. Adding small amounts of water will suppress plagioclase crystallization, in particular (e.g., Eggler, 1972; Baker and Eggler, 1983; Spulber and Rutherford, 1983). Because this effect may be less pronounced for olivine (and augite), it is likely that even small amounts of $\mathrm{H}_{2} \mathrm{O}$ are sufficient to suppress plagioclase to below olivine crystallization for perhaps up to $8 \%-12 \%$ crystallization before plagioclase starts crystallizing. Michael and Chase (1987) suggested that $0.1 \%-0.3$ wt $\% \mathrm{H}_{2} \mathrm{O}$ should be sufficient to suppress plagioclase crystallization in mid-ocean ridge basalts $25^{\circ} \mathrm{C}$, to below the olivine crystallization by about $5^{\circ} \mathrm{C}$. They suggested that such an effect may explain $\mathrm{Al}_{2} \mathrm{O}_{3}$-enrichment and $\mathrm{FeO}$-depletion in some ridge basalts.

The crystallization models developed for the major elements were tested using a pair of relatively incompatible and compatible elements $(\mathrm{Zr}$ and $\mathrm{Ni})$, as shown in Figure 9. The calculations use distribution coefficients for Ni from Conrad and Kay (1984) and for $\mathrm{Zr}$ based on the ranges compiled by Wilson (1989). Although the calculated variations, in general, explain the major differences in the trace-element contents for the two groups of rocks, only by assuming a higher parental $\mathrm{Zr}$ value can the enriched and evolved rocks at Site 797 satisfactorily be explained (Fig. 9). The two models shown in Figure 9 are based on initial $\mathrm{Zr}$ contents of 79 and $120 \mathrm{ppm}$, respectively.

The importance of olivine in the fractionate $(22 \%-29 \%)$ is not easily explained because this phase is lacking in the groundmasses of the evolved suites (Thy, this volume, a). All suites of magmas can be predicted to crystallize olivine relatively early and eventually to reach the augite-saturated cotectic (Fig. 5). Subsequent crystallization may 


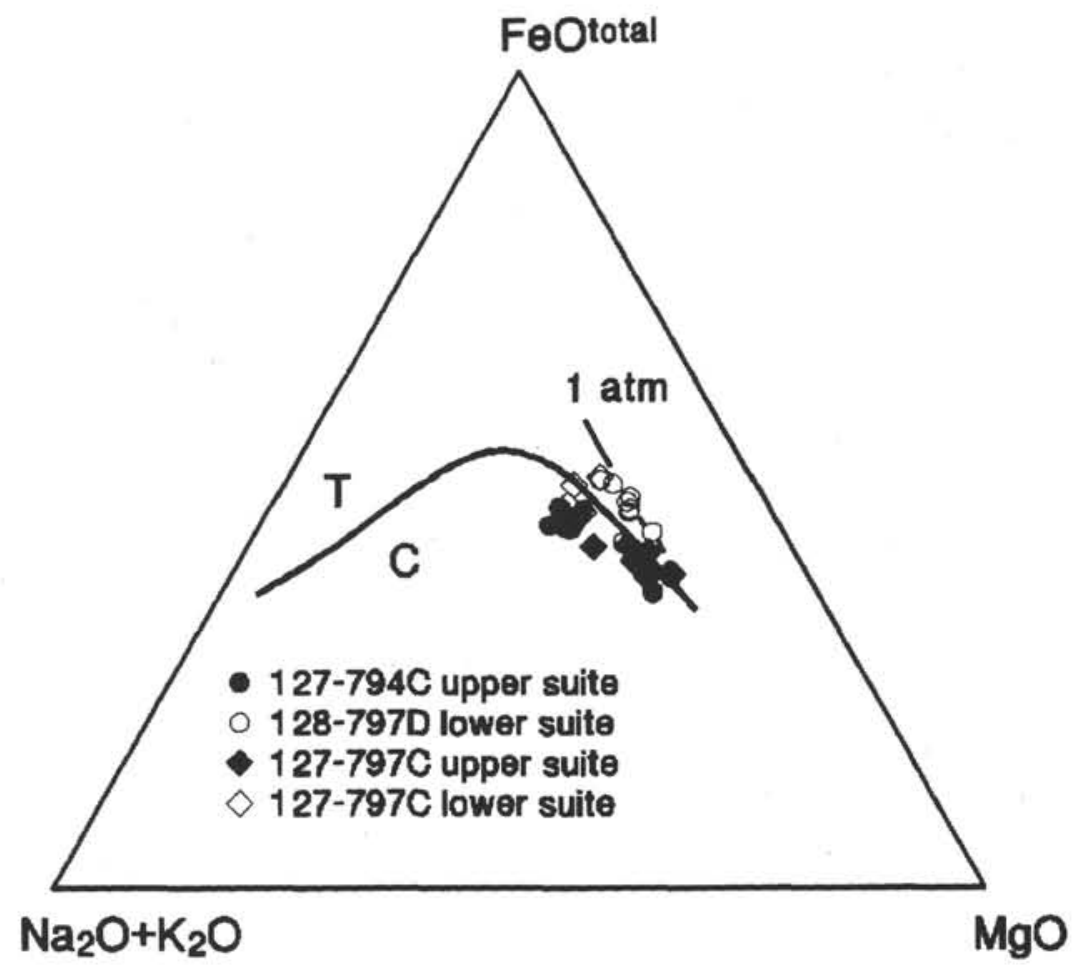

Figure 4. AFM diagram $\left(\mathrm{Na}_{2} \mathrm{O}+\mathrm{K}_{2} \mathrm{O}, \mathrm{FeO}^{\text {total }}, \mathrm{MgO}\right)$ of the Yamato Basin rocks. The data are as for Figure 3. The dividing line between the tholeiitic $(\mathrm{T})$ and calc-alkalic $(\mathrm{C})$ rock series is from Irvine and Baragar (1971). The line marked " $1 \mathrm{~atm}$ " is the liquid line of descent determined by Thy (this volume, b).

bring the liquids to the pseudo-invariant cotectic, where olivine will be replaced by a low-Ca pyroxene (Grove et al., 1982; Grove and Baker, 1984). However, low-Ca pyroxenes were not observed in any of the examined rocks. Furthermore, there are no indications that any of the magmas might reach low-Ca pyroxene saturation before reaching augite saturation (Fig. 5). It is possible that the Japan Sea rocks might reach pseudo-univariant olivine, augite, plagioclase, and magnetite cotectic relations before reaching low-Ca pyroxene saturation and these may involve a reaction curve between olivine, pyroxene, and magnetite (cf. Eggler and Osborn, 1982). This may explain the absence of low-Ca pyroxene and olivine in the evolved sills, and is consistent with the presence of magnetite as a late crystallizing phase. Thy (this volume, a) suggested that augite started to precipitate approximately after olivine ceased to crystallize during groundmass crystallization and that magnetite was the last phase to appear. Therefore, the only phases during solidification of the evolved rocks will be plagioclase, augite, and magnetite. Detailed interpretations of the groundmass crystallization are complicated by extensive alteration and the relatively small amounts of low-Ca pyroxenes that can be predicted eventually to crystallize. Nevertheless, patches of groundmass that are completely unaltered and low-Ca pyroxene-free appear in many samples.

\section{Middle Miocene Volcanic Rocks of Northeast Japan}

Extensive basaltic submarine volcanism, composed of pillow lavas, volcaniclastic materials, and dike and sill swarms occurred at the back-arc side of the northeastern Japan arc during the middle Miocene, simultaneously with the opening of the Japan Sea. The volcanic rocks are overlain by thick marine sediments, indicating subsequent regional subsidence
(Tsuchiya, 1989, 1990). Tsuchiya (1988) described the volcanic rocks from the Akita-Yamagata area, and Shuto et al. (1988) described the rocks from the Tappi region. According to Tsuchiya (1988, 1990), extrusive basaltic rocks consist mainly of olivine and plagioclase phyric and augite, olivine, and plagioclase phyric basalts. Hypersthene was observed in some olivine doleritic sills. The major element variations in the rocks analyzed by Tsuchiya (1988) and Shuto et al. (1988) are shown in Figure 10 and compared to the calculated models for the Japan Sea rocks. The rocks show large variations, in particular evident for $\mathrm{Na}_{2} \mathrm{O}$ and $\mathrm{CaO}$, which have been attributed to low-temperature alteration (Tsuchiya, 1988). Despite this complication, a trend exists toward increasing $\mathrm{Al}_{2} \mathrm{O}_{3}$ and constant $\mathrm{TiO}_{2}$ with falling $\mathrm{MgO}$ contents, which is consistent with the delayed plagioclase fractionation model developed for the Japan Sea rocks. However, $\mathrm{FeO}$ content appears to increase with falling $\mathrm{MgO}$, similar to the Fe-enrichment trend observed for the Japan Sea rocks. This Fe-enrichment trend is real, as Tsuchiya (1988) observed a correspondent enrichment in the composition of augite phenocrysts. Augite is not a phenocryst in any of the Site 794 and 797 rocks, and mineralogically and chemically, the middle Miocene rocks are not easily interpreted in terms of the results for the Japan Sea. This is surprising because the northeast Japan volcanic rocks have been attributed to a failed rift that developed in the peripheral part of the spreading Japan Sea (Tsuchiya, 1990). Unfortunately, compositional and mineralogical information from Site 795 is insufficient to allow a reliable comparison with the northeast Japan rocks. For comparison, Figure 10 also shows analyses of lava flows from the back-arc spreading basin of the Mariana Trough (Sinton and Fryer, 1979). These data correspond to the Fe-enrichment trend for the Japan Sea rocks, although departures are observed, in particular for $\mathrm{Al}_{2} \mathrm{O}_{3}, \mathrm{TiO}_{2}$, and $\mathrm{FeO}$. These have been related to slight hydrous conditions and low-pressure melting by Sinton and Fryer (1987). 

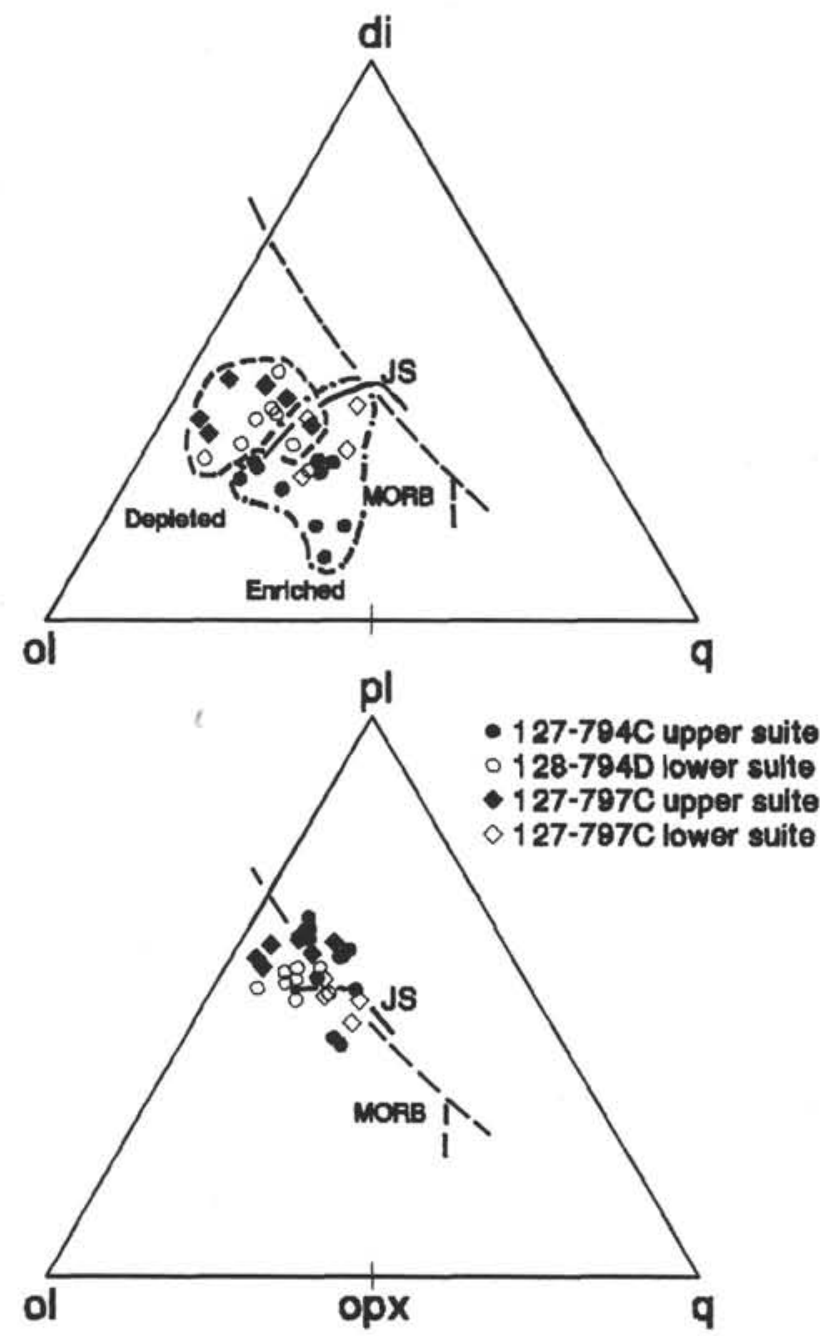

Figure 5. Pseudoternary normative projections of the Yamato Basin basalts of Sites 794 and 797. Data and reduction are as for Figure 3. The projections are based on a CIPW molecular norm similar to that used by Presnall et al. (1979), but with Fe redistributed according to Kilinc et al. (1983) for the FMQ oxygen buffer and temperatures estimated according to the experimental results (cf. text to Fig. 3). The fields occupied by the enriched and the depleted magma types are outlined. The full drawn line marked "JS" is the one-atmosphere liquid line of descent determined for an olivine-bearing, Site 797 basalt (Thy, this volume, b); the bend in the liquid line of descent marks the start of crystallization of augite. The dashed line marked "MORB" is the one-atmosphere, liquid line of descent for mid-ocean ridge basalts determined by Walker et al. (1979), Grove and Bryan (1983), and Tormey et al. (1987). Ol = olivine; $\mathrm{di}=$ diopside; $\mathrm{q}=$ quartz; opx = hypersthene.

\section{CONCLUSIONS}

The basaltic flows and sills recovered at Sites 794 and 797 in the Yamato Basin of the Japan Sea represent, from the point of major and minor elements, two distinct magma types: (1) a K-depleted, olivinebearing type and (2) a K-enriched, olivine-bearing to dominantly evolved, olivine-free type. These two magma types are present at both sites, although their relative positions in the drill holes vary. Olivine appears to have a limited crystallization interval and is not present in the groundmasses of the evolved rocks. It is suggested that this might reflect reaction relationships among liquid, olivine, augite, and magnetite. The precipitation of augite and magnetite in the evolved group of rocks, therefore, may limit olivine crystallization during ground- mass solidification. The evolved sills reveal two contrasting evolution trends. One can be attributed to high degrees of crystal fractionation $(40 \%-50 \%)$, involving plagioclase, olivine, and augite, and is reflected in increasing $\mathrm{FeO}$ and $\mathrm{TiO}_{2}$ and decreasing $\mathrm{Al}_{2} \mathrm{O}_{3}$ with increasing fractionation. The other records relatively low degrees of olivine fractionation $(8 \%-12 \%)$ and appears as slightly decreasing $\mathrm{FeO}$, increasing $\mathrm{Al}_{2} \mathrm{O}_{3}$, and nearly constant $\mathrm{TiO}_{2}$ with advancing degrees of fractionation. The former is a tholeiitic evolution trend, which is consistent with the experimentally determined, one-atmosphere liquid line of descent. The latter shows a mildly calc-alkalic evolution trend. It is suggested that the main differences between these two contrasting trends can be related to the effect of small amounts of water during formation of the calc-alkalic suites. There is evidence for this in calcic plagioclase phenocrysts of some of the sills. Augites became relatively subcalcic in the anhydrous suites and calcic in the hydrous suites. Except for the inferred differences in water content, there is no evidence that the parental magmas, in terms of major and minor elements, should differ significantly. However, if trace elements are considered it is revealed that parental magmas vary in terms of their relative abundances of some trace elements (cf. Cousens and Allan, this volume).

The calc-alkalic suites occur in the stratigraphically highest positions in the drilled crust, while the tholeiitic suites occur in the lowest positions. In addition, the enriched and depleted magma types are represented among both the stratigraphically upper and the lower suites. This suggests a complex magmatic and tectonic evolution of the Japan Sea, perhaps reflecting the transition between subduction zone activity and back-arc spreading (Tamaki, 1985, 1988). The depleted suites are good candidates for a back-arc spreading-related magma, while the enriched suites may be subduction zone related. It is possible that both types of magmas were produced simultaneously and that the first-formed magma batches were relatively hydrous, while subsequent batches became dryer as back-arc spreading became more dominating. Another explanation for the observed differences in liquid lines of descent may be related to the depth of residence of crustal magma chambers and consequently their ability to retain a volatile component. However, better constraints from trace element studies as well as detailed dating of the rocks will be needed in order further to evaluate these possibilities.

\section{ACKNOWLEDGMENTS}

The author is in debt to the Leg 127 shipboard scientific party and crew for providing the geological background and samples, and to K. Stewart, S. Yamashita, and J. Allan for discussion and introduction to the petrogenesis of the Japan Sea. S. Yamashita and A. Pouclet kindly allowed me to use their analyses of Leg 127 and 128 rocks prior to publication. Comments from D. R. Baker and B. Cousens greatly improved the manuscript. This work was initiated during an U.S. National Research Council-NASA Research Associateship. The Danish Natural Science Research Council supported the author during Leg 127.

\section{REFERENCES}

Arculus, R. J., and Wills, K.J.A., 1980. The petrology of plutonic blocks and inclusions from Lesser Antilles island arc. J. Petrol., 21:743-799.

Baker, D. R., and Eggler, D. H., 1983. Fractionation paths of Atka (Aleutians) high-alumina basalts: constraints from phase relations. J. Volcanol. Geotherm. Res., 18:387-404.

, 1987. Compositions of anhydrous and hydrous melts coexisting with plagioclase, augite, and olivine or low-Ca pyroxene from $1 \mathrm{~atm}$ to $8 \mathrm{kbar}$ : application to the Aleutian volcanic center of Atka. Am. Mineral., 72:12-28.

Baker, M. B., and Grove, T. L., 1985. Kinetic controls on pyroxene nucleation and metastable liquid lines of descent in a basaltic andesite. Am. Mineral., 70:279-287.

Biggar, G. M., 1984. The composition of diopside solid solutions, and of liquids, in equilibrium with forsterite, plagioclase, and liquid in the system 
$\mathrm{Na}_{2} \mathrm{O}-\mathrm{CaO}-\mathrm{MgO}-\mathrm{Al}_{2} \mathrm{O}_{3}-\mathrm{SiO}_{2}$ and in remelted rocks from 1 bar to $12 \mathrm{kbar}$. Mineral. Mag., 48:481-494.

Conrad, W. K., 1987. A FORTRAN program for simulating major and trace element variations during Rayleigh fractionation with melt replenishment or assimilation. Comput. Geosci., 13:1-12.

Conrad, W. K., and Kay, R. W., 1984. Ultramafic and mafic inclusions from Adak Island: crystallization history, and implications for the nature of primary magmas and crustal evolution in the Aleutian arc. J. Petrol. 25:88-125.

Eggler, D. H., 1972. Water-saturated and undersaturated melting relations in a Paricutin andesite and an estimate of water content in the natural magma. Contrib. Mineral. Petrol., 34:261-271.

Eggler, D. H., and Osborn, E. F., 1982. Experimental studies of the system $\mathrm{MgO}-\mathrm{FeO}-\mathrm{Fe}_{2} \mathrm{O}_{3}-\mathrm{NaAlSi}_{3} \mathrm{O}_{8}-\mathrm{CaAl}_{2} \mathrm{Si}_{2} \mathrm{O}_{8}-\mathrm{SiO}_{2}$ - a model for subalkaline magmas. Am. J. Sci, 282:1012-1041.

Green, D. H., Hibberson, W. O., and Jaques, A. L., 1979. Petrogenesis of mid-ocean ridge basalts. In McElhinny, M. W. (Ed.), The Earth: Its Origin, Structure and Evolution: London (Academic Press), 265-299.

Green, T. H., and Ringwood, A. E., 1968. Genesis of the calc-alkaline rock suite. Contrib. Mineral. Petrol., 18:105-162.

Grove, T. L., and Baker, M. B., 1984. Phase equilibrium controls on the tholeiitic versus calc-alkaline differentiation trends. J. Geophys. Res., 89:3253-3274.

Grove, T. L., and Bryan, W. B., 1983. Fractionation of pyroxene-phyric MORB at low pressure: an experimental study. Contrib. Mineral. Petrol., 84:293-309.

Grove, T. L., Gerlach, D. C., and Sando, T. W., 1982. Origin of calc-alkaline series lavas at Medicine Lake volcano by fractionation, assimilation and mixing. Contrib. Mineral. Petrol., 80:160-182.

Hanson, G. N., and Langmuir, C. H., 1978. Modelling of major elements in mantle-melt systems using trace element approaches. Geochim. Cosmochim. Acta, 42:725-742.

Helz, R. T., 1973. Phase relations of basalts in their melting ranges at $\mathrm{P}_{\mathrm{H}_{2} \mathrm{O}}=5$ kb. Part I. Mafic phases. J. Petrol., 14:249-302.

Ingle, J. C., Jr., Suyehiro, K., von Breymann, M. T., et al., 1990. Proc. ODP, Init. Repts., 128: College Station, TX (Ocean Drilling Program).

Irvine, T.N., and Baragar, W.R.A., 1971. A guide to the chemical classification of the common volcanic rocks. Can. J. Earth Sci., 8:523-548.

Johnson, M. C., and Rutherford, M. J., 1989. Experimental determined conditions in the Fish Canyon tuff, Colorado, magma chamber. J. Petrol., 30:711-737.

Kilinc, A., Carmichael, I.S.E., Rivers, M. L., and Sack, R. O., 1983. The ferric-ferrous ratio of natural silicate liquids equilibrated in air. Contrib. Mineral. Petrol., 83:136-140.

Lindsley, D. H., 1983. Pyroxene thermometry. Am. Mineral., 68:477-493.

MacDonald, G. A., and Katsura, T., 1964. Chemical composition of Hawaiian lavas. J. Petrol., 5:82-133.
Michael, P. J., and Chase, R. L., 1987. The influence of primary magma composition, $\mathrm{H}_{2} \mathrm{O}$ and pressure on mid-ocean ridge basalt differentiation. Contrib. Mineral. Petrol., 96:245-263.

Presnall, D. C., Dixon, J. R., O'Donnell, T. H., and Dixon, S. A., 1979. Generation of midocean tholeiites. J. Petrol., 20:3-35.

Rutherford, M. J., and Devine, J. D., 1988. The May 18, 1980, eruption of Mount St. Helens. 3. Stability and chemistry of amphibole in the magma chamber. J. Geophys. Res., 93:11949-11959.

Shuto, K., Takimoto, T., Sakai, A., Yamazaki, T., and Takahashi, T., 1988. Geochemical variation with time of the Miocene volcanic rocks in northern part of the Northeast Japan arc. Chishitsugaku Zasshi, 94:155-172. (In Japanese with English abstract)

Sinton, J., and Fryer, P., 1987. Mariana trough lavas from $18^{\circ} \mathrm{N}$ : implications for the origin of back arc basin basalts. J. Geophys. Res., 92:12782-12802.

Spulber, S. D., and Rutherford, M. J., 1983. The origin of rhyolite and plagiogranite in oceanic crust: an experimental study. J. Petrol., 24:1-25.

Tamaki, K., 1985. Two modes of back-arc spreading. Geology, 13:475-478. , 1988. Geological structure of the Japan Sea and its tectonic implications. Chishitsu Chosasho Geppo, 39:269-365.

Tamaki, K., Pisciotto, K., Allan, J., et al., 1990. Proc. ODP, Init. Repts., 127: College Station, TX (Ocean Drilling Program).

Thy, P., 1991. High and low pressure phase equilibria of a mildly alkalic lava from the 1965 Surtsey eruption: experimental results. Lithos, 26:223-243.

Tormey, D. R., Grove, T. L., and Bryan, W. B., 1987. Experimental petrology of normal MORB near the Kane fracture zone: $22^{\circ} 25^{\circ} \mathrm{N}$, mid-Atlantic ridge. Contrib. Mineral. Petrol., 96:121-139.

Tsuchiya, N., 1988. Distribution and chemical composition of the middle Miocene basaltic rocks in Akita-Yamagata oil fields of northeastern Japan. Chishitsugaku Zasshi, 94:591-608. (In Japanese with English abstract) ,- 1989 . Submarine basalt volcanism of Miocene Aosawa formation in the Akita-Yamagata oil field basin, back-arc region of Northeast Japan. Mem. Geol. Surv. Jpn., 32:399-408.

, 1990. Middle Miocene back-arc rift magmatism of basalt in the NE Japan arc. Chishitsu Chosasho Geppo, 41:473-505.

Walker, D., Shibata, T., and DeLong, S. E., 1979. Abyssal tholeiites from the Oceanographer fracture zone. II. Phase equilibria and mixing. Contrib. Mineral. Petrol., 70:111-125.

Wilson, M., 1989. Igneous Petrogenesis: London (Unwin Hyman).

Date of initial receipt: 6 February 1991

Date of acceptance: 7 June 1991

Ms 127/128B-204 
Table 2. Fractionation models as a function of percent crystallization.

\begin{tabular}{|c|c|c|c|c|c|c|c|c|c|c|c|c|c|c|c|c|c|}
\hline$\%$ & $\mathrm{SiO}_{2}$ & $\mathrm{TiO}_{2}$ & $\mathrm{Al}_{2} \mathrm{O}_{3}$ & $\mathrm{Fe}_{2} \mathrm{O}_{3}$ & $\mathrm{FeO}$ & $\mathrm{MnO}$ & $\mathrm{MgO}$ & $\mathrm{CaO}$ & $\mathrm{Na}_{2} \mathrm{O}$ & $\mathrm{K}_{2} \mathrm{O}$ & $\mathrm{P}_{2} \mathrm{O}_{5}$ & Mg\# & $\mathrm{Zr}$ & $\mathrm{Ni}$ & $\begin{array}{l}\text { Ol } \\
\text { Fo }\end{array}$ & $\begin{array}{l}\text { Pl } \\
\text { An }\end{array}$ & $\begin{array}{l}\text { Aug } \\
\mathrm{Mg \#}\end{array}$ \\
\hline \multicolumn{18}{|c|}{ Olivine $(29 \%)$ and plagioclase $(71 \%)$ fractionation } \\
\hline 0 & 49.26 & 1.12 & 17.94 & 1.07 & 6.59 & 0.16 & 9.58 & 11.29 & 2.82 & 0.07 & 0.11 & 0.721 & 79 & 160 & 90 & 75 & \\
\hline 4 & 49.41 & 1.17 & 17.72 & 1.10 & 6.74 & 0.16 & 9.38 & 11.28 & 2.87 & 0.07 & 0.11 & 0.713 & 82 & 144 & 90 & 74 & \\
\hline 8 & 49.56 & 1.22 & 17.47 & 1.14 & 6.90 & 0.17 & 9.16 & 11.26 & 2.93 & 0.08 & 0.12 & 0.703 & 85 & 129 & 89 & 74 & \\
\hline 12 & 49.76 & 1.27 & 17.20 & 1.18 & 7.06 & 0.18 & 8.92 & 11.26 & 2.98 & 0.08 & 0.12 & 0.692 & 89 & 114 & 89 & 74 & \\
\hline 16 & 49.95 & 1.33 & 16.91 & 1.22 & 7.23 & 0.18 & 8.67 & 11.26 & 3.05 & 0.08 & 0.13 & 0.681 & 93 & 100 & 88 & 74 & \\
\hline 20 & 50.16 & 1.39 & 16.60 & 1.27 & 7.41 & 0.19 & 8.40 & 11.25 & 3.11 & 0.09 & 0.14 & 0.669 & 98 & 87 & 88 & 74 & \\
\hline 24 & 50.39 & 1.47 & 16.26 & 1.32 & 7.60 & 0.20 & 8.11 & 11.24 & 3.19 & 0.09 & 0.14 & 0.655 & 102 & 75 & 87 & 73 & \\
\hline 28 & 50.65 & 1.55 & 15.88 & 1.37 & 7.80 & 0.20 & 7.79 & 11.24 & 3.27 & 0.10 & 0.15 & 0.640 & 108 & 63 & 86 & 73 & \\
\hline 32 & 50.95 & 1.64 & 15.45 & 1.43 & 8.03 & 0.21 & 7.44 & 11.25 & 3.35 & 0.10 & 0.16 & 0.623 & 114 & 52 & 85 & 73 & \\
\hline \multicolumn{18}{|c|}{ Olivine $(22 \%)$, plagioclase $(67 \%)$, and augite $(11 \%)$ fractionation } \\
\hline 36 & 51.04 & 1.74 & 15.16 & 1.49 & 8.22 & 0.22 & 7.05 & 11.46 & 3.34 & 0.11 & 0.17 & 0.604 & 120 & 43 & 84 & 73 & 85 \\
\hline 40 & 51.15 & 1.81 & 14.93 & 1.53 & 8.39 & 0.23 & 6.84 & 11.47 & 3.36 & 0.11 & 0.18 & 0.592 & 124 & 39 & 84 & 72 & 84 \\
\hline 44 & 51.28 & 1.88 & 14.68 & 1.58 & 8.55 & 0.23 & 6.61 & 11.48 & 3.40 & 0.12 & 0.18 & 0.579 & 129 & 34 & 83 & 72 & 83 \\
\hline 48 & 51.42 & 1.96 & 14.42 & 1.63 & 8.73 & 0.24 & 6.37 & 11.49 & 3.44 & 0.12 & 0.19 & 0.565 & 135 & 30 & 82 & 72 & 83 \\
\hline 52 & 51.56 & 2.05 & 14.11 & 1.68 & 8.91 & 0.25 & 6.12 & 11.51 & 3.48 & 0.13 & 0.20 & 0.550 & 140 & 26 & 81 & 71 & 82 \\
\hline 56 & 51.73 & 2.15 & 13.80 & 1.74 & 9.10 & 0.26 & 5.85 & 11.52 & 3.52 & 0.13 & 0.21 & 0.534 & 147 & 22 & 80 & 71 & 81 \\
\hline 60 & 51.91 & 2.25 & 13.45 & 1.80 & 9.29 & 0.27 & 5.56 & 11.55 & 3.57 & 0.14 & 0.22 & 0.516 & 153 & 19 & 79 & 70 & 80 \\
\hline 64 & 52.11 & 2.37 & 13.06 & 1.86 & 9.49 & 0.28 & 5.25 & 11.58 & 3.62 & 0.14 & 0.24 & 0.496 & 161 & 16 & 78 & 70 & 78 \\
\hline \multicolumn{18}{|c|}{ Olivine $(100 \%)$ fractionation } \\
\hline 0 & 49.26 & 1.12 & 17.94 & 1.07 & 6.59 & 0.16 & 9.58 & 11.29 & 2.82 & 0.07 & 0.11 & 0.721 & 79 & 160 & 90 & & \\
\hline 4 & 49.61 & 1.17 & 18.67 & 1.07 & 6.49 & 0.16 & 7.98 & 11.74 & 2.94 & 0.07 & 0.11 & 0.687 & 82 & 99 & 88 & & \\
\hline 8 & 50.02 & 1.22 & 19.49 & 1.06 & 6.31 & 0.16 & 6.25 & 12.24 & 3.06 & 0.08 & 0.12 & 0.638 & 86 & 54 & 86 & & \\
\hline 12 & 50.48 & 1.27 & 20.37 & 1.02 & 6.02 & 0.16 & 4.51 & 12.78 & 3.20 & 0.08 & 0.12 & 0.571 & 90 & 24 & 82 & & \\
\hline 16 & 51.03 & 1.33 & 21.35 & 0.95 & 5.52 & 0.16 & 2.72 & 13.38 & 3.36 & 0.08 & 0.13 & 0.467 & 94 & 11 & 76 & & \\
\hline
\end{tabular}

Note: The fractionation models were calculated using the computer source code of Conrad (1987). The starting composition was Sample 127-797C-12R-2, 74-79 $\mathrm{cm}$ (Thy, this volume, b; table 1, analysis 1 ). The calculated liquid compositions, as well as the compositions of the removed minerals (Fo mol\% for olivine (ol); An mol\% for plagioclase (pl); $\mathrm{Mg} /(\mathrm{Mg}+\mathrm{Fe})(\mathrm{Mg} \#)$ for augite (aug)), are given as a function of percent fractionation (\%). All calculations were performed with the mineral proportions determined experimentally ( $\mathrm{wt} \%$ ), with all $\mathrm{Fe}$ calculated as $\mathrm{FeO}$, appropriate determined mineral compositions, and $\mathrm{K}_{\mathrm{D}} \mathrm{Fe} / \mathrm{Mg}$ (ol/liq) and $\mathrm{K}_{\mathrm{D}}^{\mathrm{Na} / \mathrm{Ca}}$ (pl/liq) from Thy (this volume, b). Subsequently, the liquid $\mathrm{Fe}^{2+} / \mathrm{Fe}^{3+}$ were recalculated following Kilinc et al. (1983) and experimental conditions of Thy (this volume, b). The $\mathrm{Zr}$ and $\mathrm{Ni}$ modelling were based on the major element models and variable distribution coefficients for Ni from Conrad and Kay (1984) and constant distribution coefficients for $\mathrm{Zr}$ ( 0.05 for olivine, 0.5 for augite, and 0.05 for plagioclase). Only the model using a $\mathrm{Zr}$ content for the parental magma of $79 \mathrm{ppm}$ is given. Major and minor elements are in wt\%, while trace elements are in ppm. $\mathrm{Mg} \#$ is $\mathrm{Mg} /\left(\mathrm{Mg}+\mathrm{Fe}{ }^{2+}\right)$, except for augite where it represents $\mathrm{Mg} /\left(\mathrm{Mg}+\mathrm{Fe}^{\text {total }}\right)$. The column marked " $\%$ " refers to the percent solid fractionate; zero is the starting composition. 

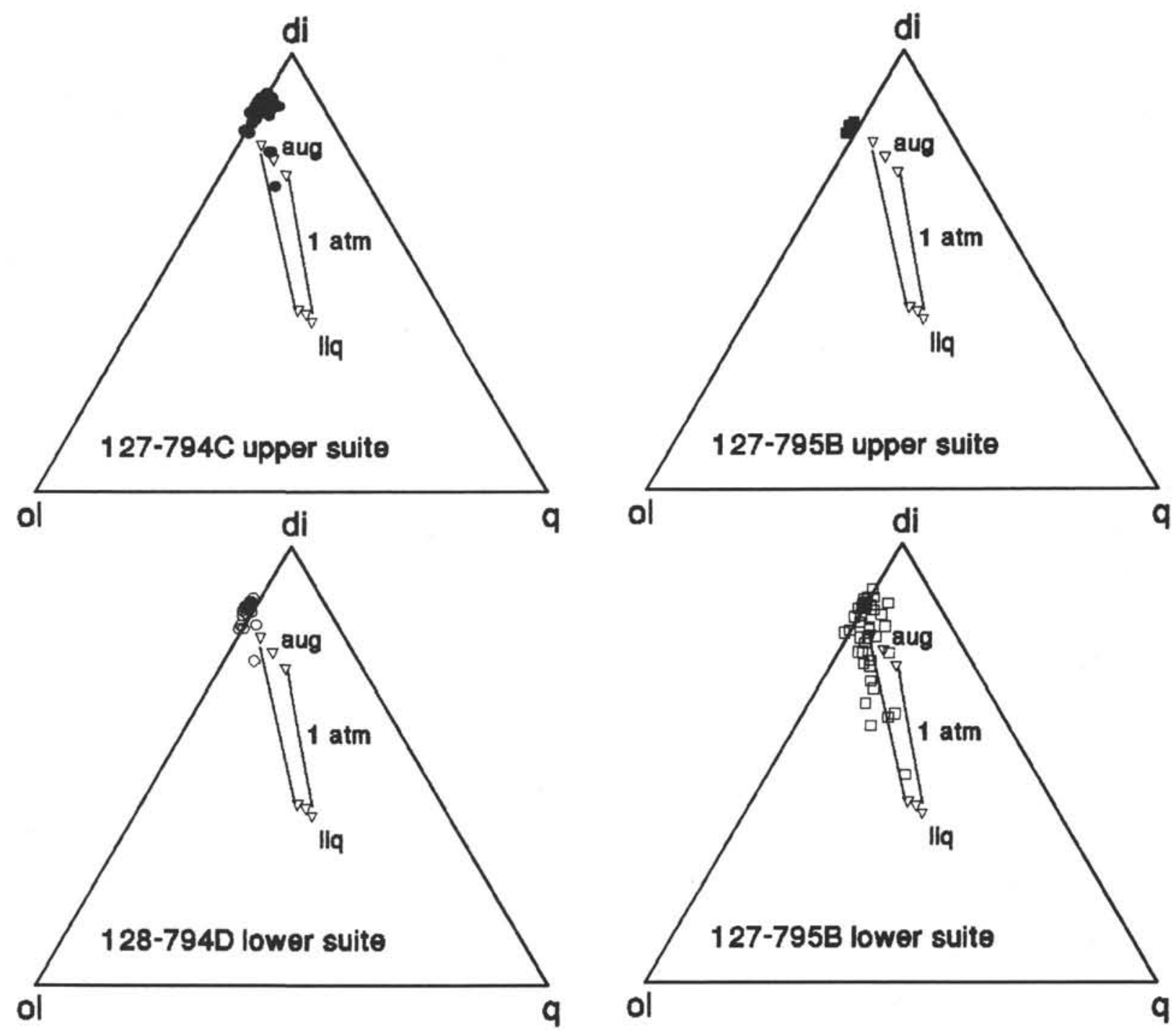

Figure 6. One-atmosphere, experimental, pyroxene-liquid relations for a Site 797 olivine basalt, compared to the natural augites from Sites 794 , 795, and 797. Calculation and projection methods are as for Figure 5. Iron of the augites has been adjusted in a similar way as for the liquids. Representative, experimental tie-lines between coexisting augite (aug) and liquid (liq) are shown. 


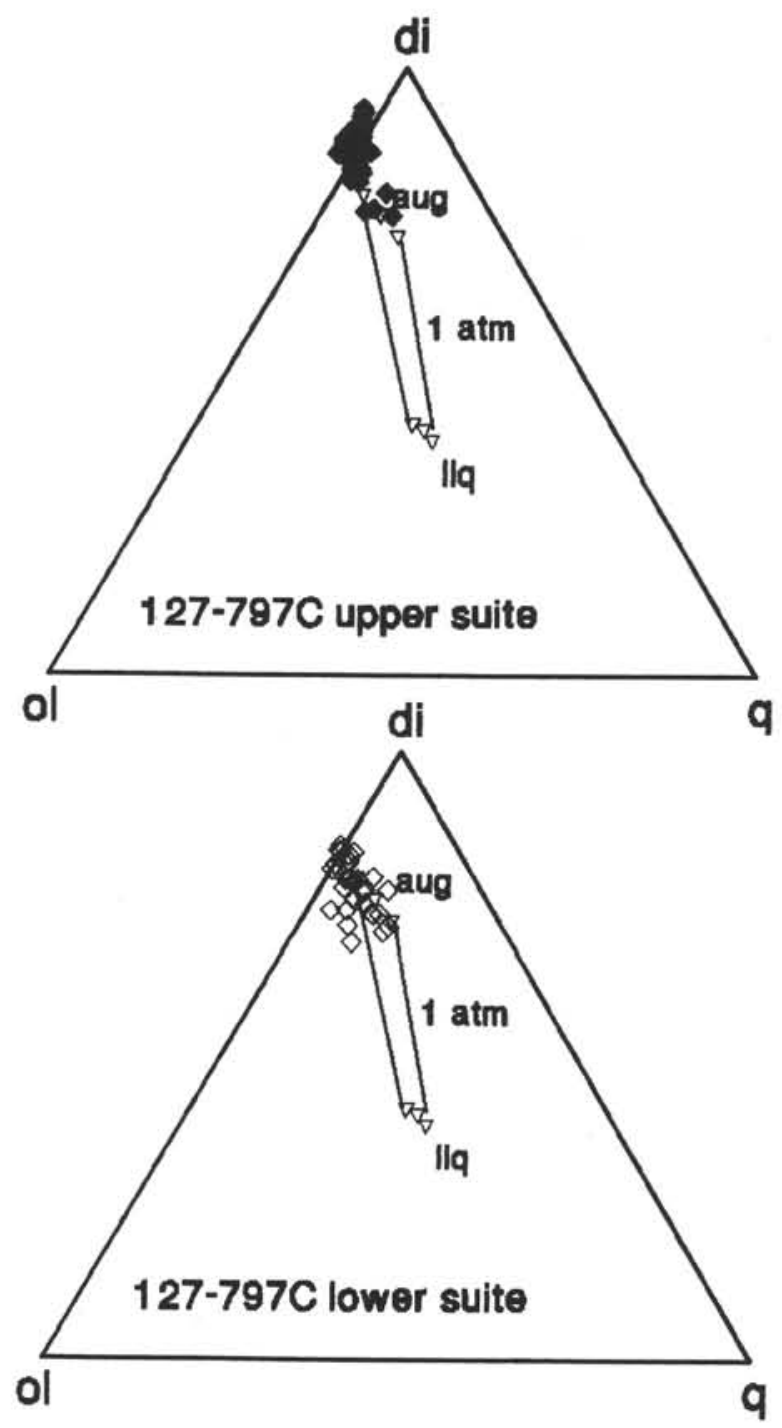

Figure 6 (continued). 
A
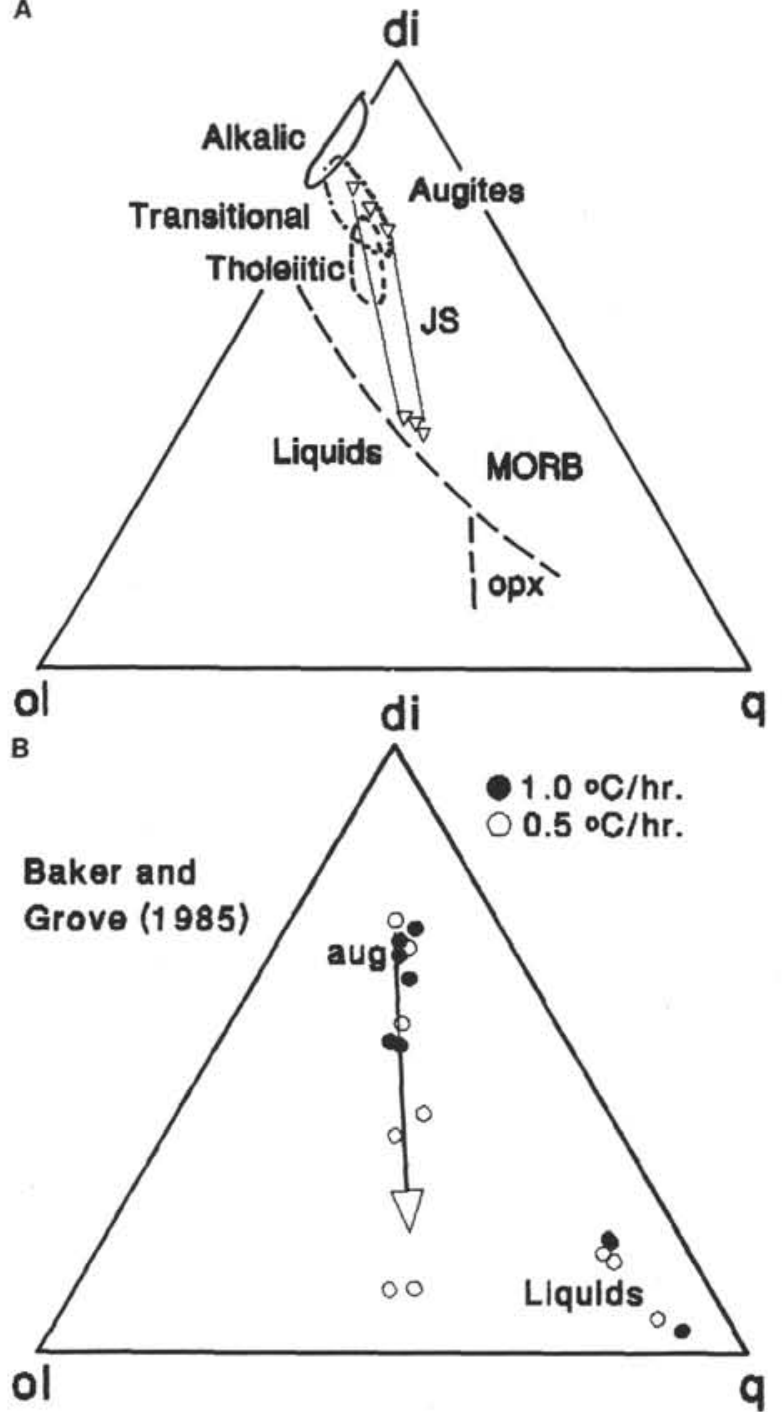

C

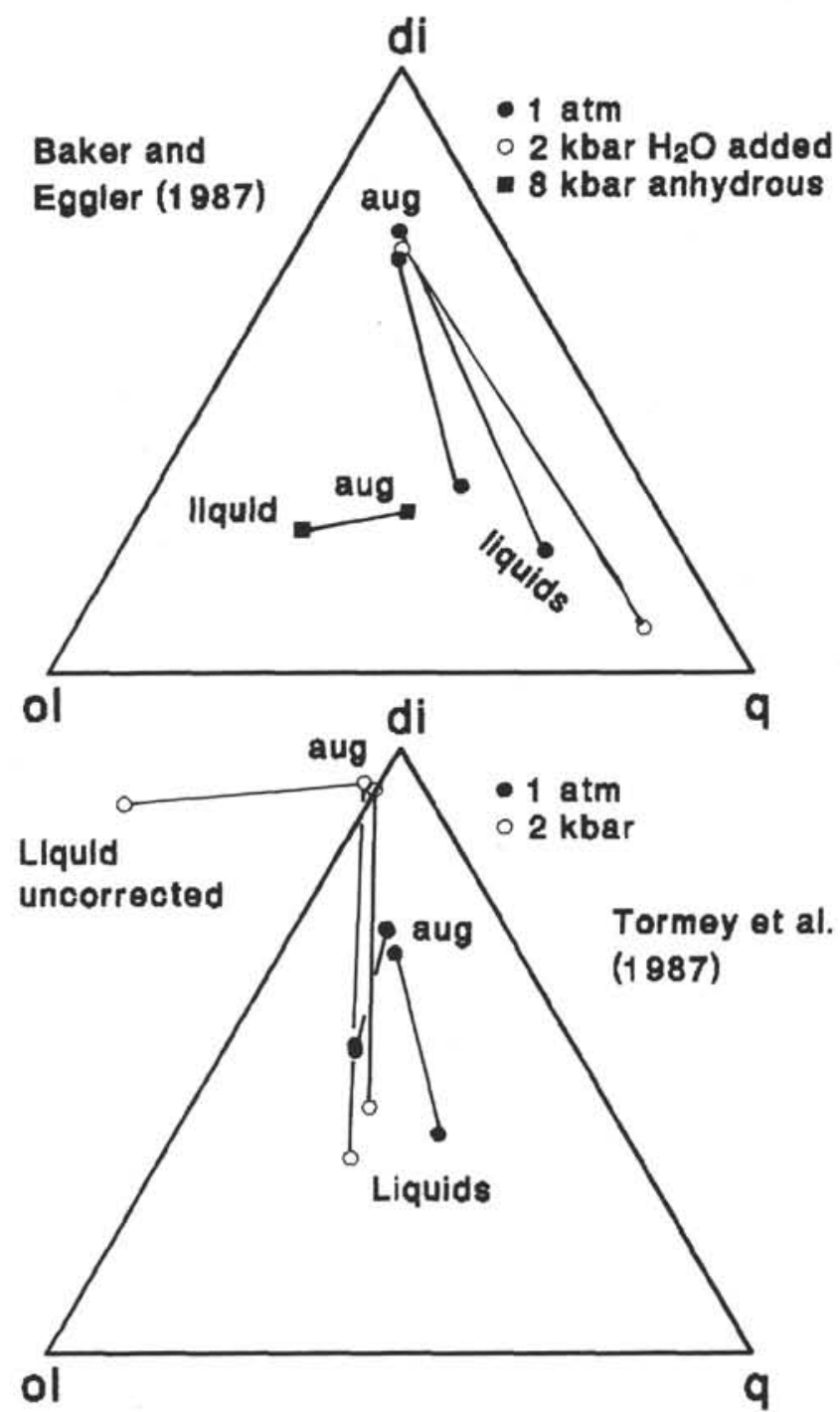

Figure 7. Experimental, pyroxene-liquid relations from various sources showing the general effects of bulk compositions, cooling rates, and anhydrous and hydrous pressures. Projection methods as for Figures 5 and 6. A. The effect of bulk compositions on augites. The general fields occupied by experimental, one-atmosphere augites of mildly alkalic, transitional, and tholeitic basalt types are outlined (Thy, 1991, and references cited therein). The coexisting augites and liquids for the Site 797 basalt are marked "JS". The liquid line of descent for mid-ocean ridge basalts (MORB) is as for Figure 5. B. The effect of cooling rate on augites (aug) crystallizing from an andesite at $1^{\circ}$ and $0.5^{\circ} \mathrm{C} / \mathrm{hr}$ (Baker and Grove, 1985). The general effect of decreasing cooling rate is shown by the arrow. C. The effect of hydrous and anhydrous pressures (Baker and Eggler, 1987). Tie-lines are given between coexisting liquids and augites (aug) as a function of pressure and the presence/absence of water in the melts during the experiments. D. An experimental data set at $1 \mathrm{~atm}$ and $2 \mathrm{kbar}$ (Tormey et al., 1987). Tie-lines connect coexisting liquids and augites (aug). The apparent anomalous nepheline-normative augites are an effect of correcting the liquid compositions for enrichment in Na and loss of Fe during the experiments. The nepheline-normative augites most likely equilibrated with a highly alkalic liquid. 

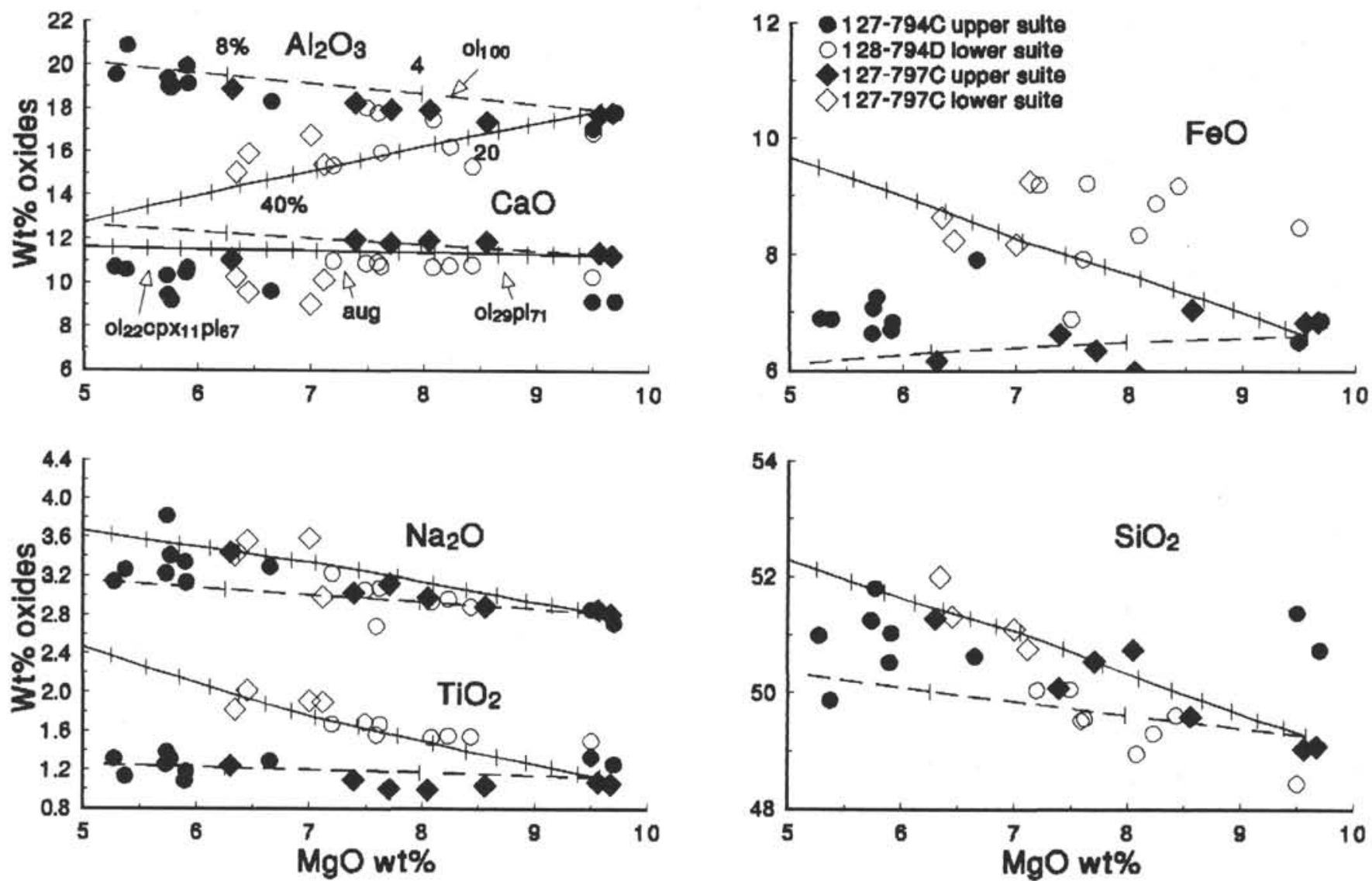

Figure 8. Fractionation models for major elements, superimposed on the $\mathrm{MgO}$ variation diagrams of Figure 3. The models were calculated using a computer source code originally developed by Conrad (1987). The $\mathrm{K}_{\mathrm{D}} \mathrm{s}$ and single-element distribution coefficients for plagioclase, olivine, and augite are those obtained experimentally (Thy, this volume, b). Two models are shown: (1) olivine, plagioclase, augite fractionation ( $\mathrm{ol}_{29} \mathrm{pl}_{71}$ and $\mathrm{ol}_{22} \mathrm{cpx}_{11} \mathrm{pl}_{67}$ ) in proportions (wt\%) consistent with the experimental results; (2) olivine fractionation alone $\left(\mathrm{ol}_{100}\right)$. The tick-marks on the calculated liquid lines of descent each mark $4 \%$ crystallization. The start of crystallization of augite (aug) is indicated along the $\mathrm{CaO}-\mathrm{MgO}$ variation curve.

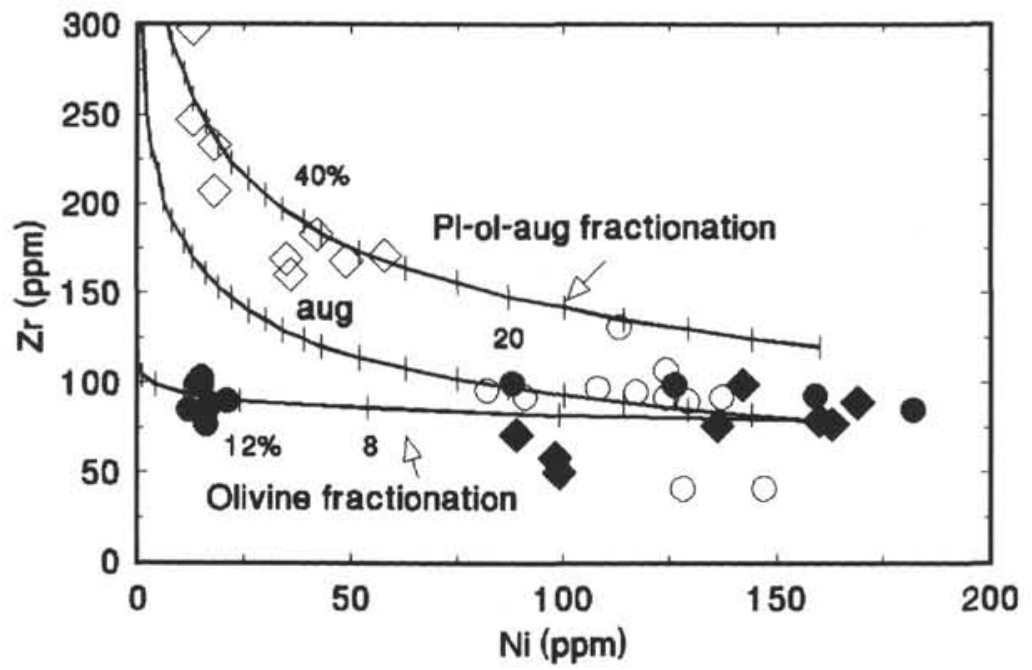

Figure 9. Fractionation models for $\mathrm{Zr}$ and $\mathrm{Ni}$ based on the same fractionation models shown in Figure 8. The distribution coefficients for $\mathrm{Ni}$ are based on Conrad (1987), while those for $\mathrm{Zr}$ have been kept constant using reasonable values $\left(\mathrm{D}_{\mathrm{Zr}}\right.$ for olivine, 0.05 ; augite, 0.5 ; plagioclase, 0.05). Two different $\mathrm{Zr}$ contents for the parental magma (79 and $120 \mathrm{ppm}$ ) are needed in order satisfactory to model the variation observed. Changing the $D$-values will affect slightly the curve, but will not affect the conclusions. The approximate start of crystallization of augite (aug) is indicated. 

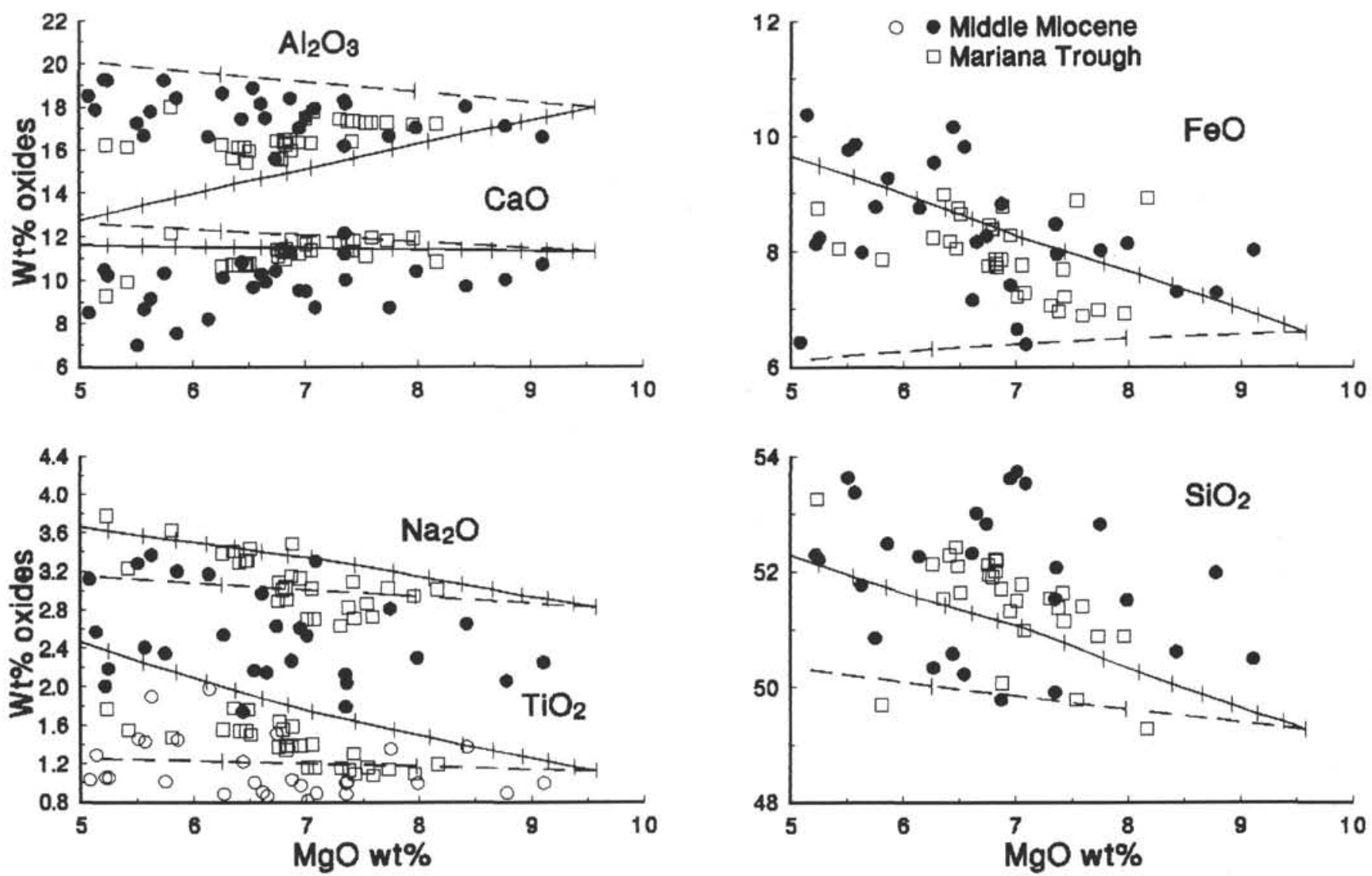

Figure 10. Middle Miocene volcanic rocks of the back-arc region of northeastern Japan. The data are from the Akita district (Tsuchiya, 1988) and from the Tappi district (Shuto et al., 1988). Lavas from the back-arc spreading center of the Mariana Trough are shown for comparison (Sinton and Fryer, 1987). Calculations and fractionation models are identical with those used to describe the Japan Sea rocks (Fig. 8). Note that two different symbols for the middle Miocene rocks have been used on the $\mathrm{Na}_{2} \mathrm{O}-\mathrm{TiO}_{2}-\mathrm{MgO}$ variation diagram in order to clarify this. 